\title{
Myeloma multiplex treatment and overall survival
}

\author{
Svetlana Krstevska Balkanov ${ }^{*}$, Sanja Trajkova ${ }^{1}$, Sonja Genadieva Stavric ${ }^{1}$, \\ Aleksandra Pivkova Veljanovska ${ }^{1}$, Marija Popova Labacevska ${ }^{1}$, Dejan Spasovski ${ }^{2}$, \\ Irena Rambabova Bushljetik ${ }^{3}$, Goce Kalcev ${ }^{4}$, Irina Panovska Stavridis ${ }^{1}$ \\ ${ }^{1}$ University Clinic for Hematology, Faculty of Medicine, Ss. Cyril and Methodius University in Skopje, \\ Mother Theresa 17, 1000 Skopje, Republic of North Macedonia \\ ${ }^{2}$ University Clinic for Rheumatology, Faculty of Medicine, Ss. Cyril and Methodius University in Skopje, \\ Mother Theresa 17, Skopje, Republic of North Macedonia \\ ${ }^{3}$ University Clinic for Nephrology, Faculty of Medicine, Ss. Cyril and Methodius University in Skopje, \\ Mother Theresa 17, Skopje, Republic of North Macedonia \\ ${ }^{4}$ University of Cagliari, Italy
}

Received: September 2021; Accepted: November 2021

\begin{abstract}
The Multiple myeloma (MM) is a plasma cell malignancy in which monoclonal plasma cells proliferate in bone marrow, resulting in an overabundance of monoclonal paraprotein (M protein), destruction of bone, and displacement of other hematopoietic cell lines.

This retrospective-prospective study was conducted at the University Clinic for Hematology in Skopje, North Macedonia, in the period between January 2009 and December 2019. Patients younger than 65 years, without comorbidities, fit for autologous peripheral blood stem cell transplantation (PBSCT), were treated with Cyclophosphamide-Thalidomide-Dexamethasone (CyThalDex) protocol divided into two daily doses which were maintained until complete remission. Patients over 65 years of age, unfit for more aggressive treatment options like peripheral blood stem cells (PBSCT) with comorbidities and renal failure, were treated with MelphalanPrednisone-Thalidomide (MPT) protocol. The third group of patients was treated without new immunomodulators such as thalidomide, but instead a salvage therapy was given consisted of chemotherapy and corticosteroids.

The use of thalidomide can lead to more undesirable effects such as deep vein thrombosis and renal neuropathy. The results obtained in our study showed no high percentage of these effects. However, a better survival rate was registered along with a longer period without progression of the underlying disease (PFS). Moreover, a higher percentage of complete remission (CR) was achieved and a very good partial response (VGPR) in general.

Myeloma multiplex is still incurable disease with pattern of regression and remission followed by multiple relapses rising from the residual myeloma cells, but in the future still many unsolved questions has to be answered.
\end{abstract}

Keywords: myeloma multiplex, autologous stem cell transplantation, thalidomide

\section{Introduction}

Plasma cell disorders are a diverse group of monoclonal diseases characterized by the presence of monoclonal plasma cell population in the bone marrow and presence of end-organ damage known as the CRAB criteria (increased calcium level, renal dysfunction, anemia, and destructive bone lesions). (Gerecke et al., 2016; Kehrer et al., 2017).

It is a genetically complex disease which develops via multistep process whereby plasma cells are driven

\footnotetext{
* svetlanakrstevskaa@yahoo.com
} 
towards malignancy through the accumulation of genetic "hits" over time. Almost all patents with monoclonal gammopathy could be diagnosed as symptomatic or asymptomatic (Morgan et al., 2012). Multiple myeloma (MM) evolves from an antecedent asymptomatic monoclonal gammopathy of undetermined significance (MGUS). Patients with a symptomatic disease should be treated immediately, whereas asymptomatic disease is subject of additional observation (van de Donk et al., 2016).

Majority of patients are over 60 years of age and the median age at diagnosis is increasing with the increase of overall life expectancy. In USA and Europe, the incidence of MM is 3 to 4 per 100,000 people (Becker, 2011; Padala et al., 2021; Vélez et al., 2016). The annual incidence of MM in Macedonia is 2.5 per 100,000 people, with a noticeable progress in the past 5 years for $39 \%$ per year (Bila et al., 2021). MM is a malignant disorder that arises from the malignant proliferation of plasma cells and is characterized by the presence of at least $10 \%$ clonal bone marrow plasma cells and serum and/or urinary monoclonal proteins. Symptomatic disease could be defined with so called CRAB features: C-hypercalcemia $(>11.5 \mathrm{mg} / \mathrm{dL}$ (2.65 mmol/L); R-Renal failure; serum creatinine (> 177 mmol/L; $\quad(>2 \mathrm{mg} / \mathrm{dL})) ; \quad$ A-anemia (hemoglobin $<10 \mathrm{~g} / \mathrm{dL} ; 12.5 \mathrm{mmol} / \mathrm{L}$ ) or $2 \mathrm{~g} / \mathrm{dL}$ below the lower normal limit; and B-bone disease (lytic lesions, severe osteopenia or pathologic fractures) (Ludwig et al., 2014). Patients are stratified into three risk groups based on the levels of serum beta 2-micro globulin and albumin at the moment of diagnosis according to International Staging System (ISS). Nowadays, the revised ISS (R-ISS) includes, in addition to ISS, the level of lactate dehydrogenase (LDH) in serum and some high-risk cytogenetic abnormalities, and allows identification of very high-risk patients (Palumbo et al., 2015). Chromosomal abnormalities $\mathrm{t}(4 ; 14), \mathrm{t}(14 ; 16)$ and $\mathrm{t}(14 ; 20)$ chromosome 1 abnormalities and del17 detected by fluorescent in situ hybridization (FISH) are associated with a poor prognosis (Giri et al., 2020). Hyperdiploidy, $\mathrm{t}(11 ; 14), \mathrm{t}(6 ; 14)$, is associated with a good prognosis and can be considered a "standard risk" (Chretien et al., 2015). Although median and overall survival (OS) has been estimated to be approximately 3-4 years, some patients with MM may live longer than 10 years (Fonseca et al., 2017). Prognosis and treatment decisions depend on various prognostic factors including age, performance score, comorbidities. In addition, different treatment approaches (younger patients are treated with high-dose therapies), individual initial response to treatment, disease-free survival time, and occurrence of relapse are important issues (Palumbo et al., 2015).

In order to allow uniform reporting, the International Myeloma Working Group (IMWG) has defined several response subcategories in MM patients: complete response (CR), very good partial response (VGPR), partial response $(\mathrm{PR})$, stable disease (SD), and progressive disease (PD).
Response to treatment is a major prognostic factor in MM, regardless the age of the patient (Durie et al., 2006).

MM management has undergone profound changes in the past owing to advances in our understanding of the disease biology and improvements in treatment and supportive care approaches. The outcome in patients with MM has improved substantially over the past 20 years due to several therapeutic advances. High-dose therapy (HDT) with autologous stem cell transplantation (ASCT) was developed in the $90 \mathrm{~s}$ as the standard front-line treatment for younger and fit patients but it was not adequate for the treatment and overall survival of MM patients (Moreau et al., 2015). In the 2000s, the introduction of novel agents such as thalidomide, lenalidomide, bortezomib and others have changed the therapeutic scenario in MM in several ways and it has become possible to achieve CR and VGPR and longer lasting disease-free survival time and overall survival (Moehler et al., 2006).

The immunomodulatory effect of thalidomide is expressed by the inhibition of de novo immunoglobulin $\mathrm{M}$ (IgM) antibodies synthesis. This effect is fulfilled as a result of the modulation of $\mathrm{T}$ cell immunity by increasing the inhibitory effect on tumor necrosis factor (TNF)-alpha and the antiangiogenetic impact on neovascularization. In recent decades, thalidomide in combination with dexamethasone has been introduced as a drug of choice or as a "gold standard" in the inductive treatment of newly diagnosed MM (Kim et al., 2017). Following the success of thalidomide, several of its analogues (lenalidomide and pomalidomide) have been gradually developed and clinically tested (Galustian et al., 2009). Another new molecular target approach discovered recently is the proteosomal inhibitor bortezomib, which has shown promising clinical results (Mersin et al., 2021).

The principal purpose of this study was to evaluate treatment options of MM as well as outcomes in the Republic of North Macedonia, and to show the association between age, comorbidity and renal involvement. Chromosome aberrations and their impact on survival, together with the implementation of different therapeutic approaches at our Clinic in the period of 2009-2019 in overall survival were also a subject of analysis.

\section{Materials and methods}

This retrospective-prospective study was conducted at the University Clinic for Hematology in Skopje, North Macedonia, in the period between January 2009 and December 2019. The cohort group was consisted of 296 newly diagnosed patients with MM. There were 146 (49.3\%) female and $150(50.7 \%)$ male patients, at the age ranging from 31 to 88 years (mean age 62 years). Diagnostic criteria of MM were based on the IMWG (Rajkumar et al., 2014). Patients were stratified in various treatment groups after staging of the disease (by IMWG), age, comorbidity status, and renal impairment. Patients 
younger than 65 years, without comorbidities, fit for autologous PBSCT, were treated with Cyclophosphamide-Thalidomide-Dexamethasone

(CyThalDex) protocol divided into two daily doses which were maintained until complete remission. Molecular and/or cytogenetic analyses were done in only 46 patients. Patients over 65 years of age, unfit for more aggressive treatment options like peripheral blood stem cells (PBSCT) with comorbidities and renal failure, were treated with Melphalan-Prednisone-Thalidomide (MPT) protocol. The third group of patients was treated without new immunomodulators such as thalidomide, but instead, a salvage therapy was given consisted of chemotherapy and corticosteroids.

A written informed consent was obtained from all patients before starting the study. All medical history data were taken from patients' record database at the University Clinic for Hematology-Skopje.

\section{Statistical analysis}

Statistical analysis was made using the SPSS software, version 22. We used the Kaplan-Mayer survival curves (cumulative proportion surviving). The following survival analyses were done in this study: percentiles of survival analysis (comparison of two samples), Log Rank test (comparison of multiple samples) and Chi-square (Descriptive statistics - median, mean of survival times).

\section{Results}

A total of 296 patients with MM were involved in this study realized between the period of January 2009 and December 2019. There were $146(49.3 \%)$ female and 150 $(50.7 \%)$ male patients. Median age was 62.0 years (range 31-88 years). Four patients were younger than 40 years
(1.4\%), a total of 120 patients $(40.5 \%)$ were at the age between 40 and 59 years and 172 patients $(58.1 \%)$ were older than 60 years. Approximately $2 / 3$ of the patients were older than 60 years. We evaluated the overall survival time of patients with MM in relation to age at the time of the diagnosis. It was noted that $26 \%$ of patients above 65 years of age survived over 60 months, and $40 \%$ of patients under 65 years of age survived over 60 months. According to Log Rank Test $(p=0.00047)$ there was a statistically significant difference between the two subgroups in relation to survival of patients under and over 65 years of age. The survival median time in patients older than 65 years was 18.3 months and in patients under 65 years 43.4 months (Fig. 1).

Molecular and chromosome analyses were performed in $46 \mathrm{MM}$ patients, which showed normal findings in most of them $(41.3 \%) ; 13 \%$ showed hyperdiploid and patients with normal and hypodiploid results were stratified as patients with a standard risk, $54.3 \%$ of them. In $10.9 \%$ of $\mathrm{MM}$ patients hypodiploid was registered (gain 1q, loss 1p) and del13q, in $6.5 \% \mathrm{t}(11 ; 14) \mathrm{t}(4 ; 14)$ were registered, and in $2.2 \%$ (only one patient) del17p. In $15.2 \%$ of patients a multiple finding was registered. There were $45.7 \%$ patients with high risk for MM. We evaluated the survival time of patients with $\mathrm{MM}$ in relation to molecular and chromosome stratification and it was shown that $20 \%$ of them were with high risk [patients with hypodiploid (gain1q, loss1p) Del17p, Del13q, $\mathrm{t}(11 ; 14) \mathrm{t}(4 ; 14)$ and multiple mutations] who survived 60 months and the survival median time in these patients was 20.8 months. In patients with MM who had a standard risk, death outcome was not registered during the observation period. Log-Rank test $(W W=4.6275$, Sum=8.1880, Var=2.0767, Test statistic $=3.211191$, $p=0.00132$ ) showed a statistically significant difference between MM patients with a standard risk and those with a high risk (Fig. 2).

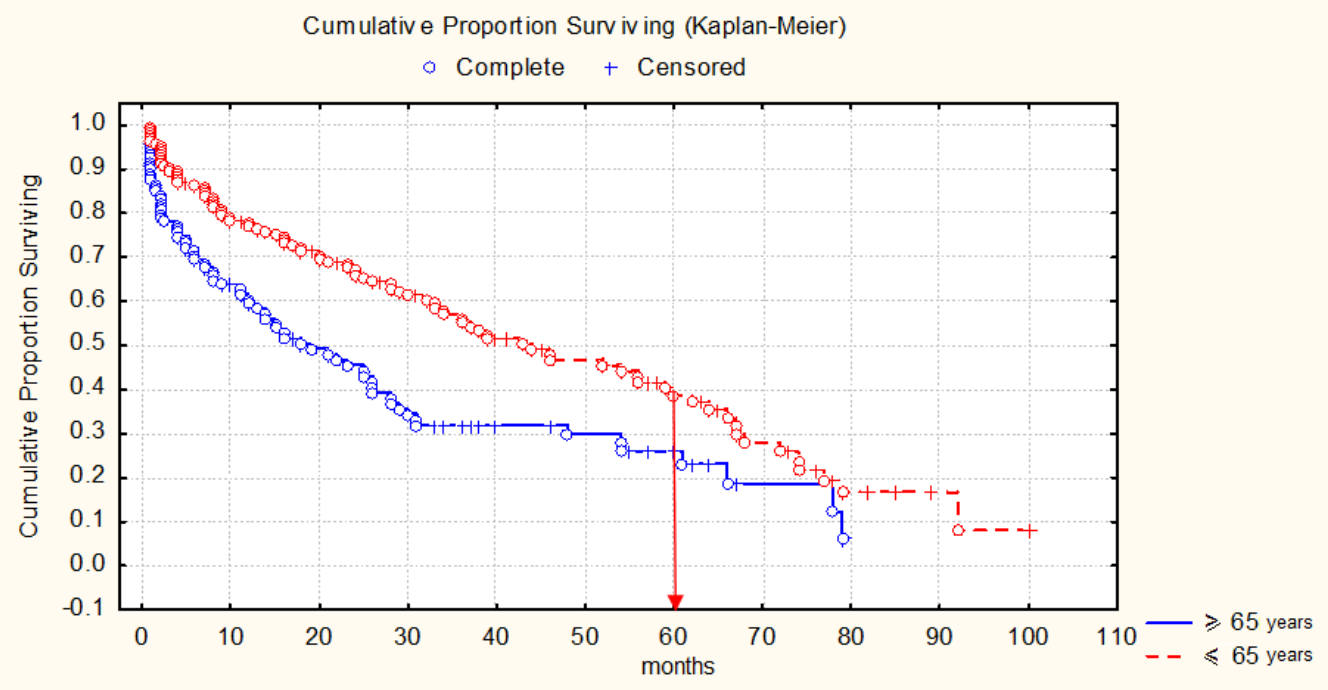

Fig. 1. Overall survival in patients according to age.

Макед. фарм. билт., 67 (1) 79 - 90 (2021) 


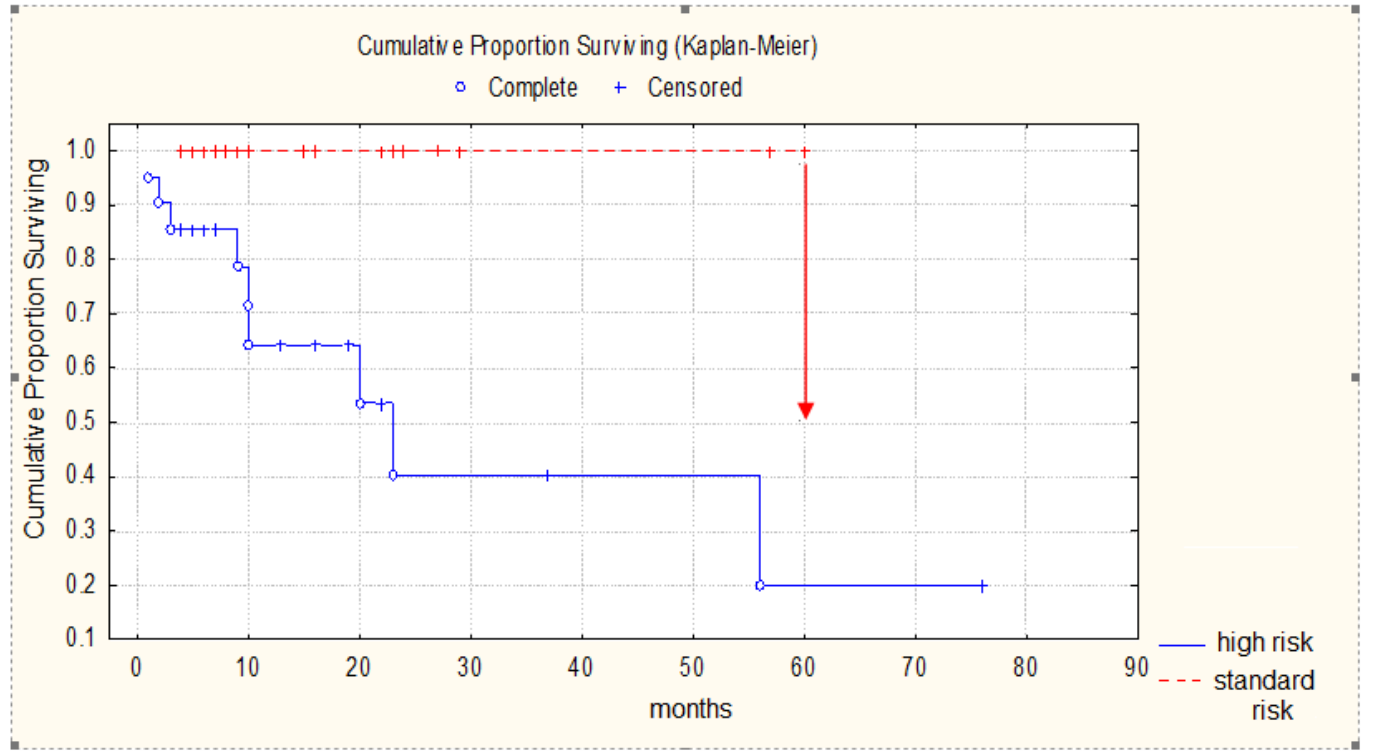

Fig. 2. Overall survival according to high and standard risk in MM patients (molecular and chromosome aberrations).

The overall survival time was evaluated in patients with and without comorbidities before performing diagnostic procedures. It was noted that $49 \%$ of patients without comorbidities survived over 60 months, and $16 \%$ of patients with comorbidities survived over 60 months. Log-Rank test $(p=0.00000)$ registered a statistically significant effect between patients with comorbidities and patients without, prior to diagnostic procedures in relation to survival. The survival median rate in patients without comorbidities prior to diagnostic procedures was 59.3 months and in patients with comorbidities 10.7 months (Fig. 3).

We evaluated $134(45.3 \%)$ patients that were treated with CTD protocol, 64 patients (21.6\%) treated with MTP protocol, 65 patients (22\%) treated with chemotherapy by Melphalan-Prednisone (MP), CyclophosphamideOncovin-Melphalan-prednisone (COMP), VincristineAdriamycin- Dexamethasone (VAD), and without thalidomide in their initial treatment. Twenty-five patients $(8.4 \%)$ were treated with various chemotherapy with thalidomide, and only 8 patients $(2.7 \%)$ were left without any therapy. Evaluation after frontline therapy was made, and we discovered CR in $16.4 \%$ of CTD group and in $6.3 \%$ of MTP group. VGPR had $43.3 \%$ of CTD patients, $26.2 \%$ of MPT patients, $15.4 \%$ in the group without thalidomide (MP, COMP, VAD) and $12 \%$ in the group treated with MIX (thalidomide and chemotherapy).

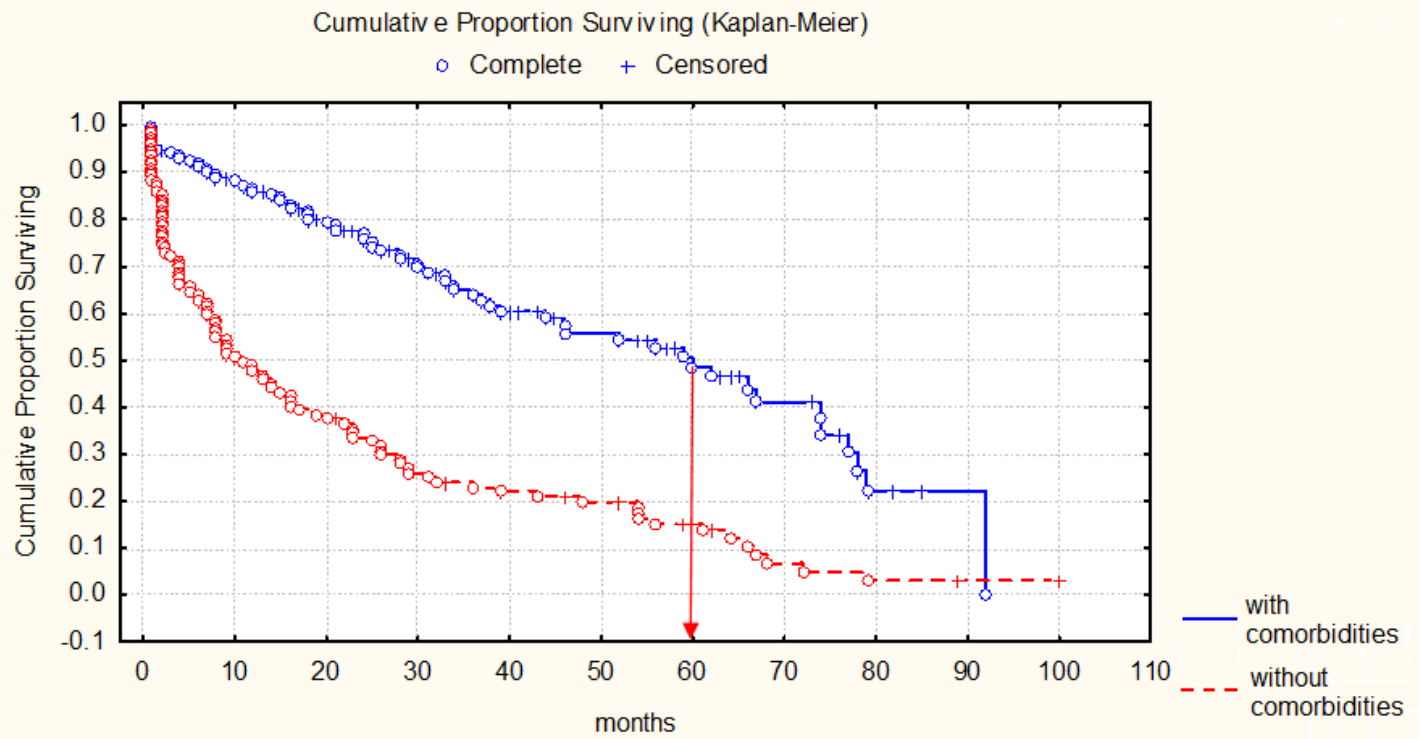

Fig. 3. Overall survivals in patients related to comorbidities. 
Table 1. Distribution according to the initial clinical response after the chemotherapy treatment

\begin{tabular}{|c|c|c|c|c|c|c|c|c|}
\hline \multirow{2}{*}{ Response/Therapy } & \multicolumn{2}{|c|}{$C T D$} & \multicolumn{2}{|c|}{$\begin{array}{c}(M P, C O M P \\
V A D)\end{array}$} & \multicolumn{2}{|c|}{$M P T$} & \multicolumn{2}{|c|}{$\begin{array}{c}(C T D, M P \\
C O M P, V A D, T D)\end{array}$} \\
\hline & $\mathrm{n}^{\circ}$ & $\%$ & $\mathrm{n}^{\circ}$ & $\%$ & $\mathrm{n}^{\circ}$ & $\%$ & $\mathrm{n}^{\circ}$ & $\%$ \\
\hline CR / VGPR & 22 & 16.4 & & & 4 & 6.3 & & \\
\hline VGPR & 58 & 43.3 & 10 & 15.4 & 17 & 26.6 & 3 & 12.0 \\
\hline PR & 21 & 15.7 & 11 & 16.9 & 21 & 32.8 & 11 & 44.0 \\
\hline $\mathrm{RD}$ & 33 & 24.6 & 44 & 67.7 & 22 & 34.4 & 11 & 44.0 \\
\hline Summary & 134 & 100.0 & 65 & 100.0 & 64 & 100.0 & 25 & 100.0 \\
\hline
\end{tabular}

CTD-cyclophosphamide-thalidomide-dexamethasone

MP-melphalan-prednisone; COMP-cyclophosphamide-vincristine-melphalan-prednisone

VAD-vincristine-doxorubicin-dexamethason

MPT-melphalan-prednisone-thalidomid

TD-thalidomide-dexamethasone; CR-complete remission

VGPR-very good partial remission; PR-partial remission

RD-refractory disease

Statistically significant $(p<0.05)$ was the response from CTD vs. other therapeutic approaches. PR was registered in $15.7 \%$ of CTD patients, $32.8 \%$ of MPT group, $16.9 \%$ of the group without thalidomide (MP, COMP, VAD) and $44 \%$ of MIX group (thalidomide and chemotherapy).

Refractory disease (RD) was registered in $24.6 \%$ of CTD patients, $34.4 \%$ of MPT group, $67.7 \%$ of patients in the group without thalidomide (MP, COMP, VAD) and $44 \%$ in MIX group.

Statistically significant $(\mathrm{p}<0.005)$ was the initial response to RD in patients without thalidomide in their treatment (MP, COMP, VAD) vs. other therapeutic modalities (Table 1).

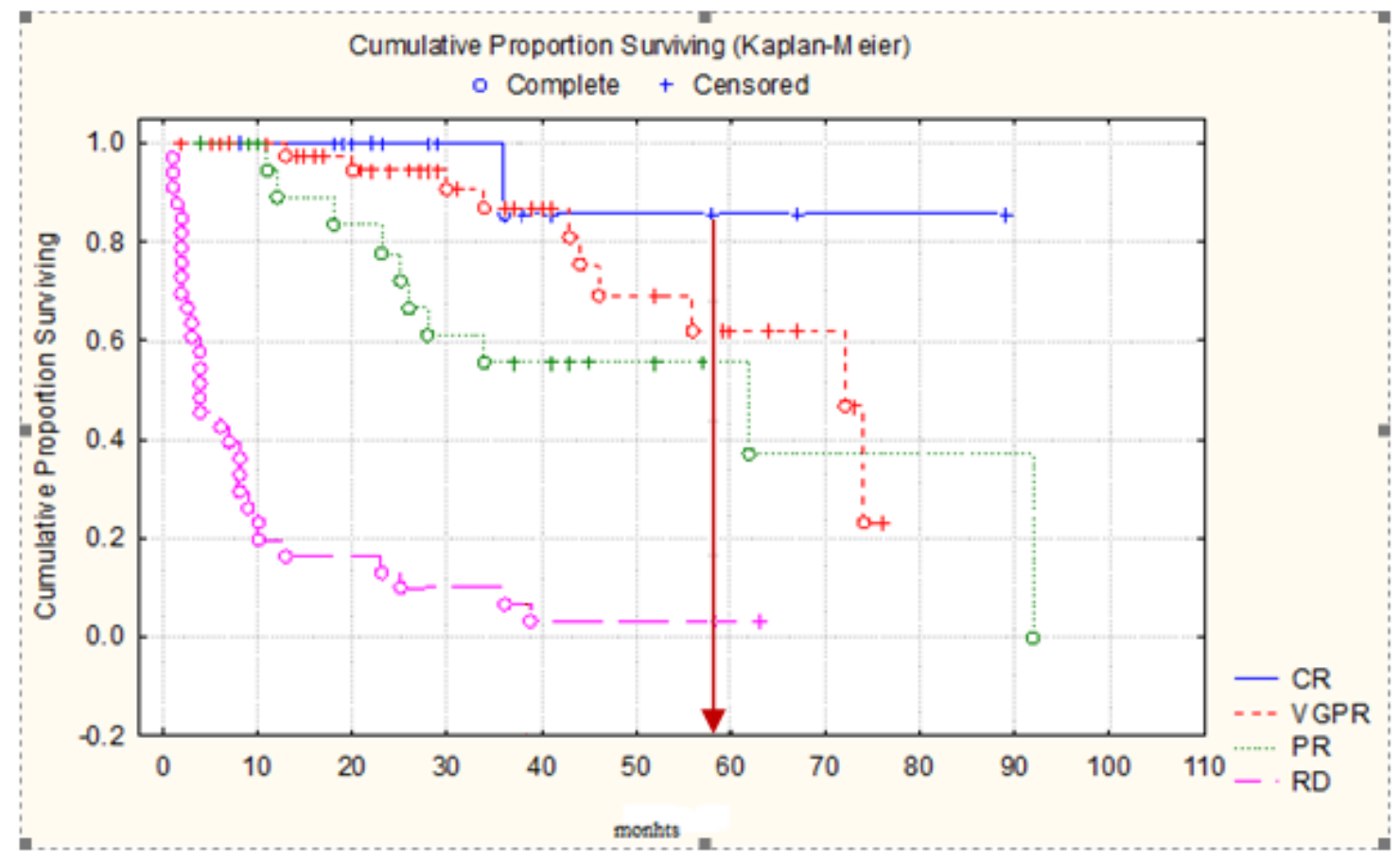

Fig. 4. Overall survivals of patients with initial response (VGPR, PR, RD) that were treated with CTD.

Макед. фарм. билт., 67 (1) 79 - 90 (2021) 


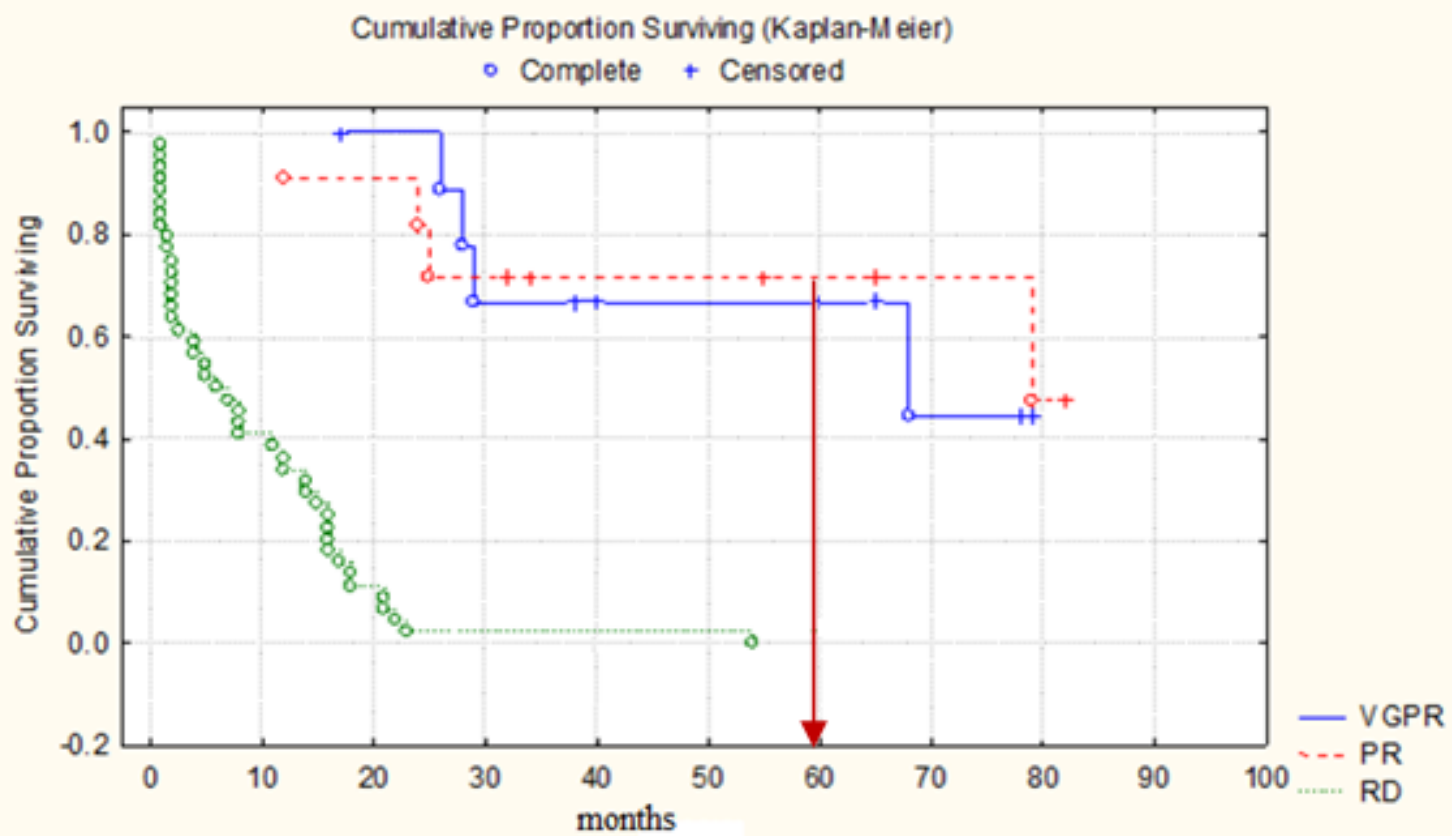

Fig. 5. Overall survival time in patients with initial response (VGPR, PR, RD) that were treated with (MP, COMP, VAD).

Patients in CTD group with CR as initial response, $61 \%$ of patients with VGPR and 55\% of patients with PR after CTD, and only $3 \%$ of patients with resistant or refractory disease $(\mathrm{RD})$ had more than 5-year- overall survival. It is clear evidence that better and deeper quality of response results in longer survival (Fig. 4).
None in the group of patients who received treatment without thalidomide (MP, COMP, VAD) showed CR. From patients with VGPR, 67\% and 70\% of patients with PR as initial response, had 5-year- overall survival. None of the patients with RD had 5-year overall survival (Fig. $5)$.

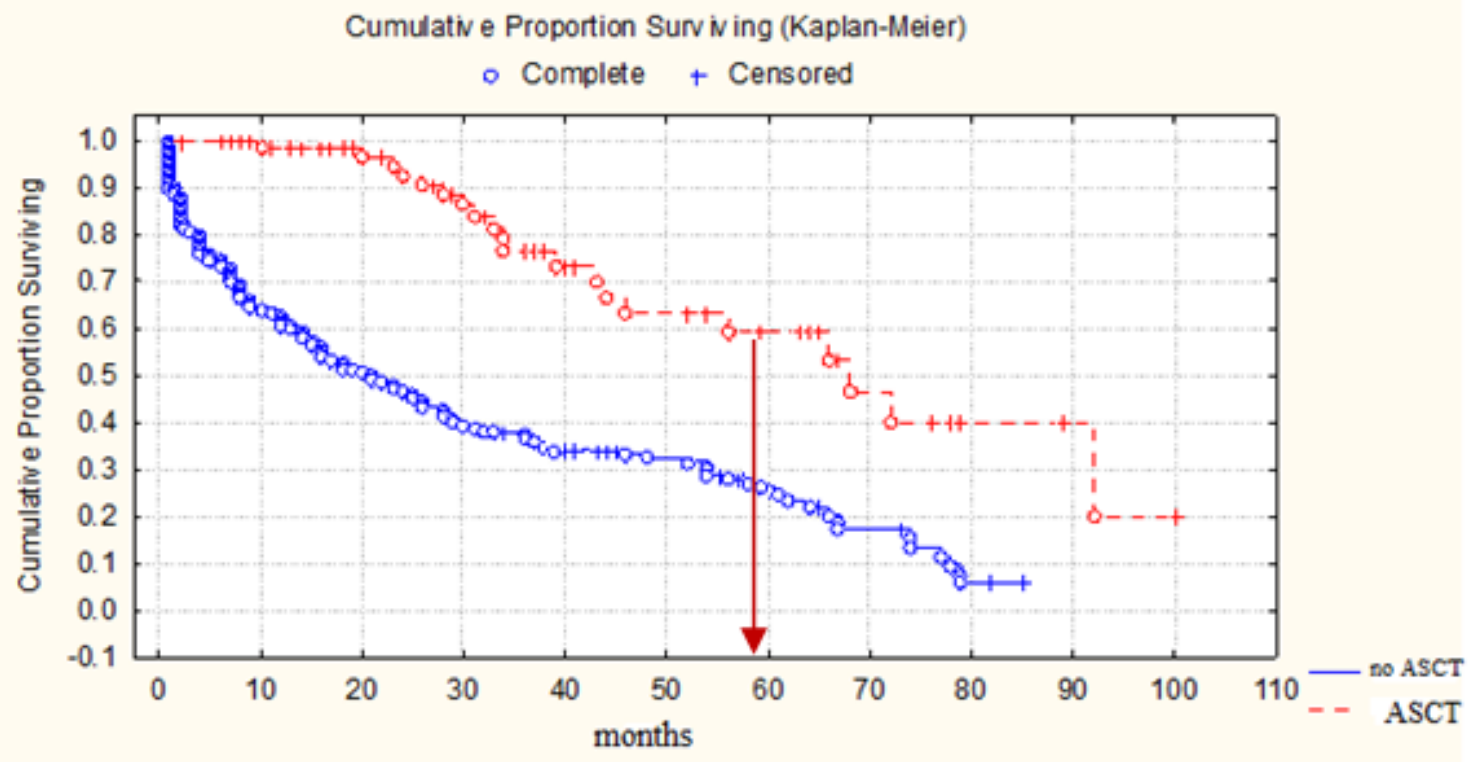

Fig. 6. Overall time of survival in patients treated \pm with ASCT. 


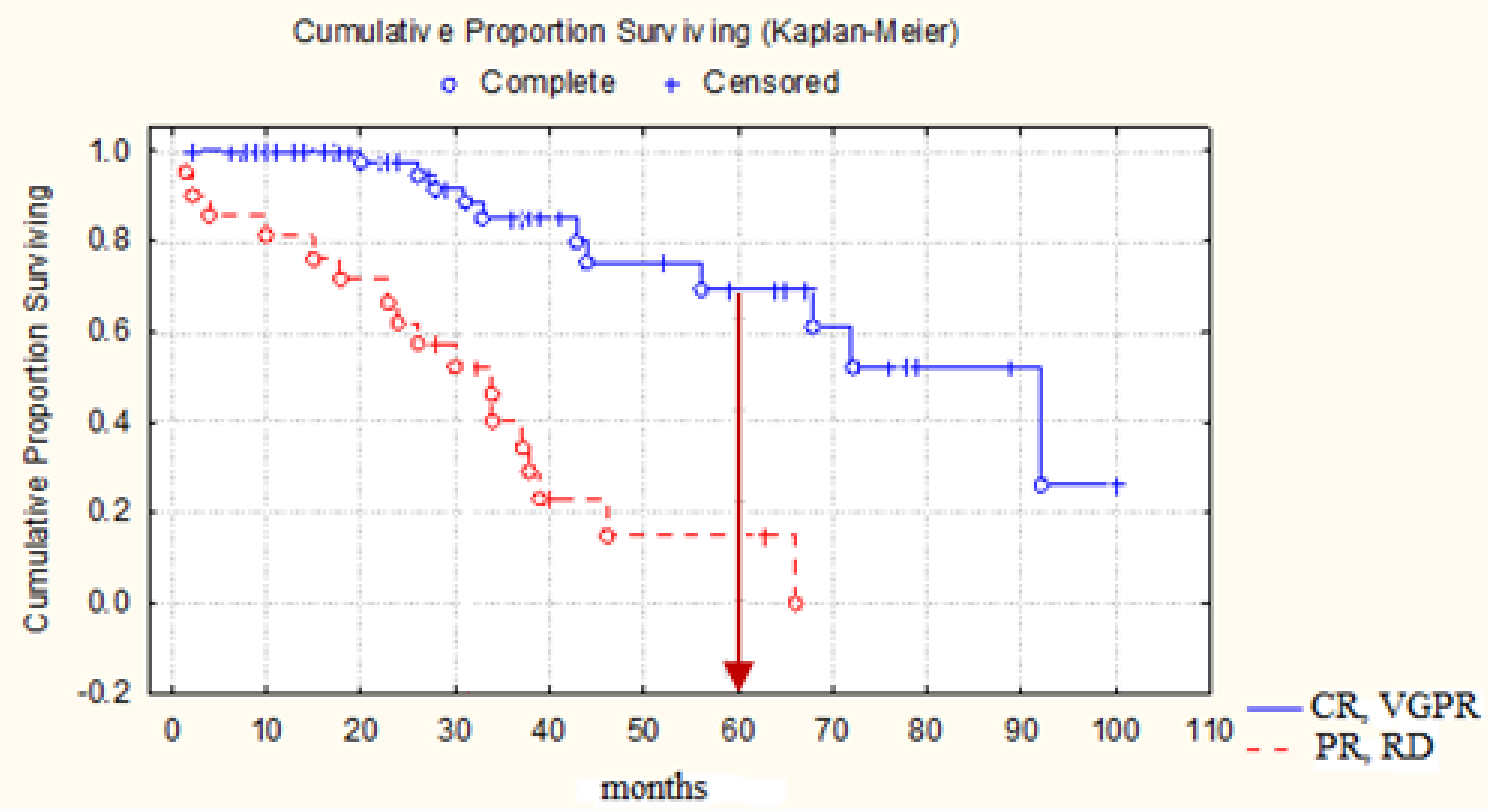

Fig. 7. Overall time of survival in patient's distribution by status before ASCT.

Seventy-four (25\%) patients were treated with ASCT and 222 patients $(75 \%)$ were not treated with this procedure. $60 \%$ of patients treated with ASCT showed overall survival of more than 5 years and $26 \%$ of patients who were not treated with ASCT had the same survival rate. Distribution of patients by status before ASCT showed 13 patients with CR (17.6\%), 48 patients (64.8\%) with VGPR, 12 patients (16.2\%) with PR, and 1 patient (1.4\%) with RD (Fig. 6).

On the other hand, $70 \%$ of patients who achieved CR and VGPR as an initial response before transplantation showed survival rate of 5 years, while patients with PR and $\mathrm{RD}$ as an initial response before transplantation showed the same survival rate, but only $18 \%$ of them $(p=0.00000)$ (Fig. 7).

Five-year-survival rate was observed in 16 patients (21.6\%) who received tandem PBSCT and 58 patients (78.4\%) had single PBSCT. 90\% of patients with tandem PBSCT were alive and $49 \%$ of them were alive the same period but they were treated with single PBSCT $(p=0.0004)$. Our group was too small to recommend tandem transplantation as a method of choice vs. single transplantation, but still, it has shown its superiority (Fig. $8)$.

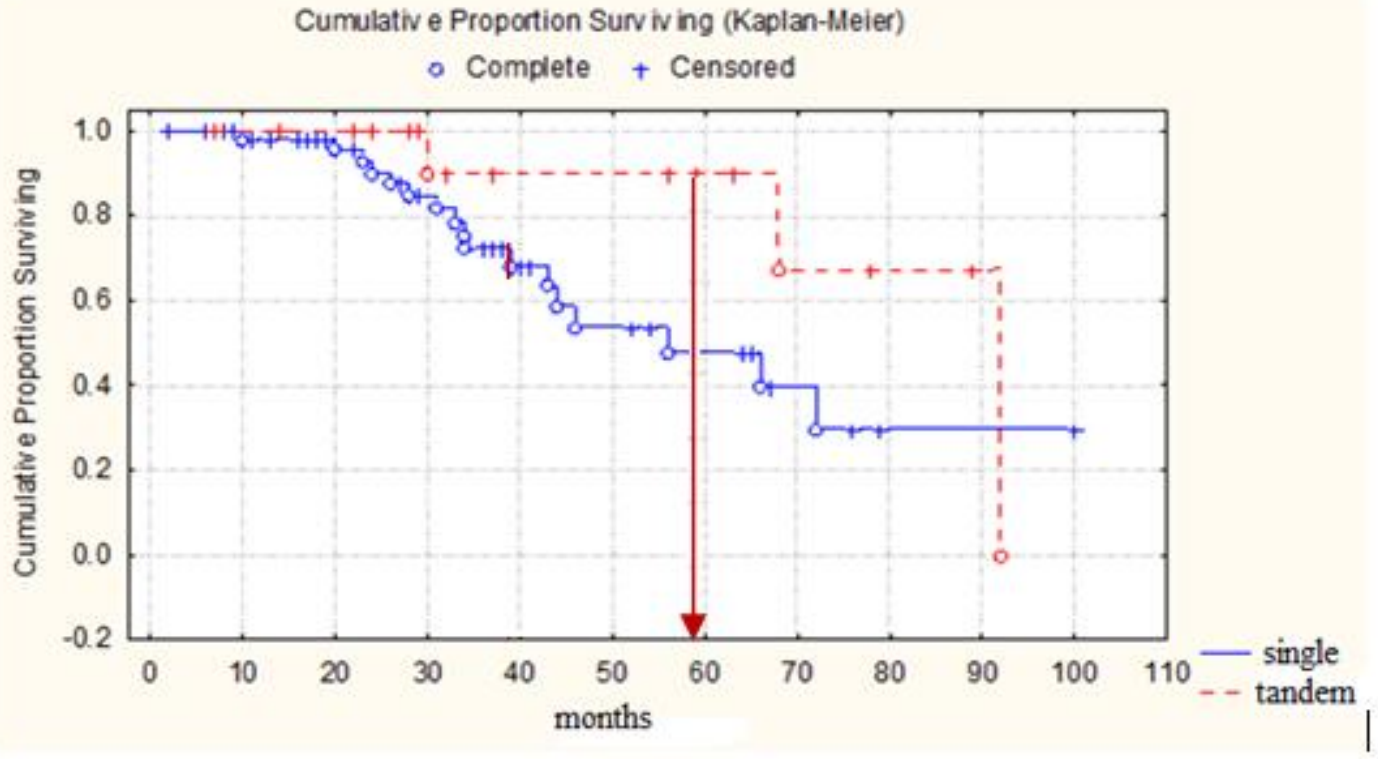

Fig. 8. Overall survival times in patients treated with tandem or single ASCT.

Макед. фарм. билт., 67 (1) 79 - 90 (2021) 


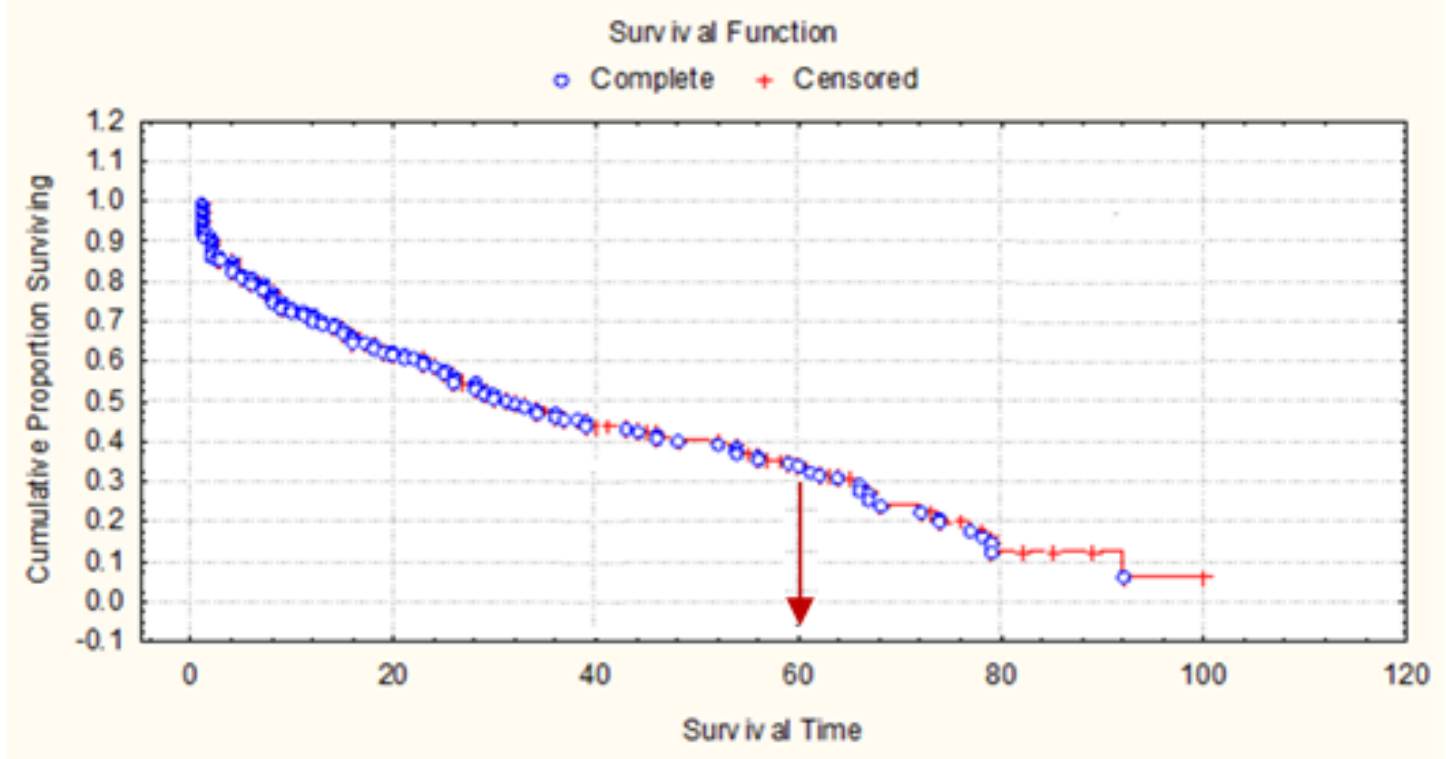

Fig. 9. Overall survival period in patients with MM during 10 years.

Thirty-five percentages of patients survived longer than 5 years, the first 20 months from diagnosis being the most critical period. The average time of survival was 40.5 months. The most common reason for mortality were the nature of the main disease and the outcome of the initial treatment (Fig. 9).

\section{Discussion}

In our study, stratification of risk factors that showed significance in the study group was done using the universal Cox Proportional model. The age was one of the most important prognostic risk factors that correlated with the poor survival of our patient population. In addition to this, according to data obtained from new studies, the age limit for drug application and autologous transplantation as methods of choice has been increased above 75 years (Bringhen et al., 2013). However, in evaluation of patients, performance scores associated with lifethreatening comorbidities, and general condition should also be considered.

Research and identification of new molecular biomarkers that would lead to benefits in personalized medicine has emerged (Katiyar et al., 2021). In our study, molecular and chromosomal analyses in patients with MM showed that $54.3 \%$ of them were at a standard risk of MM, while $45.7 \%$ of the examined patients were at a high risk of MM. This may be due to the short period of follow-up as well as to the small size of the patient population.

An important prognostic factor for reducing progression free survival (PFS) and OS is the registration of vitally threatening comorbidities (hypertension, diabetes mellitus, acute myocardial infarction) which along with age give a cross-negative effect. Analogous to this, the use of a geriatric multidisciplinary approach (Charlson index) is crucial. It is a measure of 19 comorbid conditions graded from 1-6, based on the intensity of the underlying disease. Clinical hematologists need to be aware of these criteria in order to stratify patients with MM in different treatment subgroups depending on the degree of mortality risk (Charlson et al., 1994).

As one of the predictors for reduced survival in MM patients is in fact renal involvement that is presented with an increase of the creatinine in the serum (Dimopoulos et al., 2008). In our study, $28.7 \%$ of patients had kidney impairment, compared to other studies results which presented $15-40 \%$ such patients. Also, there were only $9 \%$ of patients with acute renal failure who survived 60 months. Ten percentages of patients with registered chronic renal failure survived, and $60 \%$ of patients who had no initial renal disease from the underlying disease survived 47 months. Timely intervention leads to reversible renal impairment. It is important to recognize this type of patients according to the algorithm and to treat them in a timely manner. Also, another principal factor for negative influence on the further course of treatment was the reduced number of thrombocytes in the initial diagnostic procedures.

In our study, the key issue was the use of new drugs such as thalidomide. The combination of thalidomide plus melphalan and prednisone is superior to the classical melphalan-prednisone regimen in elderly patients. It is proven that antimyeloma efficacy and relatively minimal toxicity has led to its use in maintenance therapies after ASCT and following frontline therapy in non-transplant patients. The use of thalidomide can lead to more undesirable effects such as deep vein thrombosis and renal neuropathy. Our results have shown that a high percentage 
of these effects were not registered. However, a better survival was registered, with a longer period without progression of the underlying disease (PFS) and achieving a higher percentage of CR and VGPR in general.

Nowadays, implementation of protease inhibitors such as bortezomib in the standard initial protocols increases the percentage of complete remission and yields very good partial remission in MM patients (Mersin et al., 2021). The application of the CyThalDex protocol in young patients in good health, without the presence of vitally compromising effects, has proved to be quite effective.

One of the most important prognostic factors, which indicate longer and better overall survival, is actually the initial response (Tandon et al., 2019). This raises two essential points regarding the achievement of the desired clinical response identical in all patients, as well as factors of influence, such as the type of treatment, patient's age, clinical presentation, and biology of the disease. Thus, establishing a clinically initial response perhaps is the goal of every clinician treating a patient with MM. Our study showed that the deep initial complete response was an important predictor of all MM-related events.

Based on the results of our study, $70 \%$ of patients who reached CR and CR/ VGPR before ASCT had a survival rate of more than 60 months, while only $18 \%$ of those patients who had PR and RD before ASCT had a survival rate of more than 60 months. This is in agreement with other studies, especially regarding patients that fulfilled CR before ASCT (Harousseau, 2008). This discrepancy can be explained partially by the low CR rate obtained by conventional chemotherapy with induction protocols. On the other hand, the impact of the latter, known as the tandem ASCT is the subject of debate. While the Arkansas Group showed that the use of tandem ASCT in certain time was an important prognostic factor, Italian randomized trials found that patients achieving CR or VGPR after the first ASCT were without survival benefit from the second ASCT (Palumbo et al., 2011; Rizzo et al., 2010).

Monitoring the level of CR will help to define therapeutic strategies and to modify or prolong the treatments when the level of CR is already reached (van de Donk et al., 2021). All future treatments should include thalidomide, lenalidomide, bortezomib, or other new agents that have been clinically proven to increase OS, PFS and quality of life. Their use is associated with maximum tumor reduction, less unintended consequences and better quality of life in certain specific subpopulation of patients.

\section{Conclusion}

More aggressive initial treatment for patients that responded with CR or VGPR is matching with a longer overall survival rate with a very good quality of life. The concept of treatment of acute leukemia was applied in MM patients, or "start strong, go long" as a golden standard of the future. Another major approach for treatment of MM is the concept of personalized medicine. There is clear evidence that better and more adequate quality of response results in longer overall survival rate and improved quality of life. Myeloma multiplex is still an incurable disease with a pattern of regression and remission followed by multiple relapses raising from the residual myeloma cells, but in the future, many unsolved questions has to be answered.

\section{References}

Becker, N., 2011. Epidemiology of multiple myeloma. Recent results in cancer research. Fortschritte der Krebsforschung. Progres dans les recherches sur le cancer 183, 25-35. Available at: https://doi.org/10.1007/978-3-540-85772-3_2.

Bila, J., Katodritou, E., Guenova, M., Basic-Kinda, S., Coriu, D., Dapcevic, M., Ibricevic-Balic, L., Ivanaj, A., Karanfilski, O., Zver, S., Beksac, M., Terpos, E., Dimopoulos, M.A., 2021. Bone Marrow Microenvironment Interplay and Current Clinical Practice in Multiple Myeloma: A Review of the Balkan Myeloma Study Group. Journal of clinical medicine 10(17), 3940. Available at: https://doi.org/10.3390/jcm10173940.

Bringhen, S., Mateos, M.V., Zweegman, S., Larocca, A., Falcone, A.P., Oriol, A., Rossi, D., Cavalli, M., Wijermans, P., Ria, R., Offidani, M., Lahuerta, J.J., Liberati, A. M., Mina, R., Callea, V., Schaafsma, M., Cerrato, C., Marasca, R., Franceschini, L., Evangelista, A., Teruel, A.I., van der Holt, B., Montefusco, V., Ciccone, G., Boccadoro, M., San Miguel, J., Sonneveld, P., Palumbo, A., 2013. Age and organ damage correlate with poor survival in myeloma patients: meta-analysis of 1435 individual patient data from 4 randomized trials. Haematologica 98(6), 980-987. Available at: https://doi.org/10.3324/haematol.2012.075051.

Charlson, M., Szatrowski, T.P., Peterson, J., Gold, J., 1994. Validation of a combined comorbidity index. Journal of clinical epidemiology 47(11), 1245-1251. Available at: https://doi.org/10.1016/0895-4356(94)90129-5.

Chretien, M.L., Corre, J., Lauwers-Cances, V., Magrangeas, F., Cleynen, A., Yon, E., Hulin, C., Leleu, X., Orsini-Piocelle, F., Blade, J.S., Sohn, C., Karlin, L., Delbrel, X., Hebraud, B., Roussel, M., Marit, G., Garderet, L., Mohty, M., Rodon, P., Voillat, L., Royer, B., Jaccard, A., Belhadj, K., Fontan, J., Caillot, D., Stoppa, A.M., Attal, M., Facon, T., Moreau, P., Minvielle,S, Avet-Loiseau, H., 2015. Understanding the role of hyperdiploidy in myeloma prognosis: which trisomies really matter?. Blood 126(25), 2713-2719. Available at: https://doi.org/10.1182/blood-2015-06-650242.

Dimopoulos, M.A., Kastritis, E., Rosinol, L., Bladé, J., Ludwig, H., 2008. Pathogenesis and treatment of renal failure in multiple myeloma. Leukemia 22(8), 1485-1493. Available at: https://doi.org/10.1038/leu.2008.131.

Durie, B.G., Harousseau, J.L., Miguel, J.S., Bladé, J., Barlogie, B., Anderson, K., Gertz, M., Dimopoulos, M., Westin, J., Sonneveld, P., Ludwig, H., Gahrton, G., Beksac, M., 
Crowley, J., Belch, A., Boccadaro, M., Cavo, M., Turesson, I., Joshua, D., Vesole, D., Kyle, R., Alexanian, R., Tricot, G., Attal, M., Merlini, G., Powles, R., Richardson, P., Shimizu, K., Tosi, P., Morgan, G., Rajkumar SV., 2006. International Myeloma Working Group. International uniform response criteria for multiple myeloma. Leukemia 20(9), 1467-1473. Available at: https://doi.org/10.1038/sj.leu.2404284.

Fonseca, R., Abouzaid, S., Bonafede, M., Cai, Q., Parikh, K., Cosler, L., Richardson, P., 2017. Trends in overall survival and costs of multiple myeloma, 2000-2014. Leukemia 31(9), 1915-1921. Available at: https://doi.org/10.1038/leu.2016.380.

Galustian, C., Meyer, B., Labarthe, M.C., Dredge, K., Klaschka, D., Henry, J., Todryk, S., Chen, R., Muller, G., Stirling, D., Schafer, P., Bartlett, J.B., Dalgleish, A.G., 2009. The anti-cancer agents lenalidomide and pomalidomide inhibit the proliferation and function of T regulatory cells. Cancer immunology, immunotherapy: CII 58(7), 1033-1045. Available at: https://doi.org/10.1007/s00262-008-0620-4.

Gerecke, C., Fuhrmann, S., Strifler, S., Schmidt-Hieber, M., Einsele, H., Knop, S., 2016. The Diagnosis and Treatment of Multiple Myeloma. Deutsches Arzteblatt international 113(27-28), 470-476. Available at: https://doi.org/10.3238/arztebl.2016.0470.

Giri, S., Huntington, S.F., Wang, R., Zeidan, A.M., Podoltsev, N., Gore, S.D., Ma, X., Gross, C.P., Davidoff, A.J., Neparidze, N., 2020. Chromosome 1 abnormalities and survival of patients with multiple myeloma in the era of novel agents. Blood advances 4(10), 2245-2253. Available at: https://doi.org/10.1182/bloodadvances.2019001425.

Harousseau, J.L., 2008. Induction therapy in multiple myeloma. Hematology, American Society of Hematology, Education Program 306-312. Available at: https://doi.org/10.1182/asheducation-2008.1.306.

Katiyar, A., Kaur, G., Rani, L., Jena, L., Singh, H., Kumar, L., Sharma, A., Kaur, P., Gupta, R., 2021. Genome-wide identification of potential biomarkers in multiple myeloma using meta-analysis of mRNA and miRNA expression data. Scientific reports 11(1), 10957. Available at: https://doi.org/10.1038/s41598-021-90424-y.

Kehrer, M., Koob, S., Strauss, A., Wirtz, D.C., Schmolders, J., 2017. Multiples Myelom-aktuelle Standards in Diagnostik und Therapie [Multiple Myeloma - Current Status in Diagnostic Testing and Therapy]. Zeitschrift fur Orthopadie und Unfallchirurgie 155(5), 575-586. Available at: https://doi.org/10.1055/s-0043-110224.

Kim, E.J., Lee, J.G., Kim, J.Y., Song, S.H., Joo, D.J., Huh, K.H., Kim, M.S., Kim, B.S., Kim, Y.S., 2017. Enhanced immune-modulatory effects of thalidomide and dexamethasone co-treatment on $\mathrm{T}$ cell subsets. Immunology 152(4), 628-637. Available at: https://doi.org/10.1111/imm.12804.

Ludwig, H., Sonneveld, P., Davies, F., Bladé, J., Boccadoro, M., Cavo, M., Morgan, G., de la Rubia, J., Delforge, M., Dimopoulos, M., Einsele, H., Facon, T., Goldschmidt, H., Moreau, P., Nahi, H., Plesner, T., San-Miguel, J., Hajek, R., Sondergeld, P., Palumbo, A., 2014. European perspective on multiple myeloma treatment strategies in 2014. The oncologist 19(8), 829-844. Available at: https://doi.org/10.1634/theoncologist.2014-0042.

Mersin, S., Gedük, A., Mehtap, Ö., Tarkun, P., Ünal, S., Polat, M.G., Aygün, K., Yenihayat, E.M., Albayrak, H.,
Hacıhanifioğlu, A., 2021. Evaluation of a Generic Bortezomib Molecule in Newly Diagnosed Multiple Myeloma Patients. Turkish journal of haematology: official journal of Turkish Society of Haematology 38(3), 211-217. Available at: https://doi.org/10.4274/tjh.galenos.2021.2020.0555.

Moehler, T.M., Hillengass, J., Glasmacher, A., Goldschmidt, H., 2006. Thalidomide in multiple myeloma. Current pharmaceutical biotechnology 7(6), 431-440. Available at: https://doi.org/10.2174/13892010677911691.

Moreau, P., Attal, M., Facon, T., 2015. Frontline therapy of multiple myeloma. Blood 125(20), 3076-3084. Available at: https://doi.org/10.1182/blood-2014-09-568915.

Morgan, G.J., Walker, B.A., Davies, F.E., 2012. The genetic architecture of multiple myeloma. Nature reviews. Cancer 12(5), 335-348. Available at: https://doi.org/10.1038/nrc3257.

Padala, S.A., Barsouk, A., Barsouk, A., Rawla, P., Vakiti, A., Kolhe, R., Kota, V., Ajebo, G.H., 2021. Epidemiology, Staging, and Management of Multiple Myeloma. Medical sciences (Basel, Switzerland) 9(1), 3. Available at: https://doi.org/10.3390/medsci9010003.

Palumbo, A., Bringhen, S., Ludwig, H., Dimopoulos, M.A., Bladé, J., Mateos, M.V., Rosiñol, L., Boccadoro, M., Cavo, M., Lokhorst, H., Zweegman, S., Terpos, E., Davies, F., Driessen, C., Gimsing, P., Gramatzki, M., Hàjek, R., Johnsen, H.E., Leal Da Costa, F., Sezer, O., Spencer, A., Beksac, M., Morgan, G., Einsele, H., San Miguel, J.F., Sonneveld, P., 2011. Personalized therapy in multiple myeloma according to patient age and vulnerability: a report of the European Myeloma Network (EMN). Blood 118(17), 4519-4529. Available at: https://doi.org/10.1182/blood-2011-06-358812.

Palumbo, A., Rajkumar, S.V., San Miguel, J.F., Larocca, A., Niesvizky, R., Morgan, G., Landgren, O., Hajek, R., Einsele, H., Anderson, K.C., Dimopoulos, M.A., Richardson, P.G., Cavo, M., Spencer, A., Stewart, A. K., Shimizu, K., Lonial, S., Sonneveld, P., Durie, B.G., Moreau, P., Orlowski, R.Z., 2014. International Myeloma Working Group consensus statement for the management, treatment, and supportive care of patients with myeloma not eligible for standard autologous stem-cell transplantation. Journal of clinical oncology: official journal of the American Society of Clinical Oncology 32(6), 587-600. Available at: https://doi.org/10.1200/JCO.2013.48.7934.

Palumbo, A., Avet-Loiseau, H., Oliva, S., Lokhorst, H.M., Goldschmidt, H., Rosinol, L., Richardson, P., Caltagirone, S., Lahuerta, J.J., Facon, T., Bringhen, S., Gay, F., Attal, M., Passera, R., Spencer, A., Offidani, M., Kumar, S., Musto, P., Lonial, S., Petrucci, M.T., Orlowski, R.Z., Zamagni, E., Morgan, G., Dimopoulos, M.A., Durie, B.G., Anderson, K.C., Sonneveld, P., San Miguel, J., Cavo, M., Rajkumar, S.V., Moreau, P., 2015. Revised International Staging System for Multiple Myeloma: A Report From International Myeloma Working Group. Journal of clinical oncology: official journal of the American Society of Clinical Oncology 33(26), 2863-2869. Available at: https://doi.org/10.1200/JCO.2015.61.2267.

Rajkumar, S.V., Dimopoulos, M.A., Palumbo, A., Blade, J., Merlini, G., Mateos, M.V., Kumar, S., Hillengass, J., Kastritis, E., Richardson, P., Landgren, O., Paiva, B., Dispenzieri, A., Weiss, B., LeLeu, X., Zweegman, S., 
Lonial, S., Rosinol, L., Zamagni, E., Jagannath, S., Sezer, O., Kristinsson, S.Y., Caers, J., Usmani, S.Z., Lahuerta. J.J., Johnsen, H.E., Beksac, M., Cavo, M., Goldschmidt, H., Terpos, E., Kyle, R.A., Anderson, K.C., Durie, B.G., Miguel, J.F., 2014. International Myeloma Working Group updated criteria for the diagnosis of multiple myeloma. The Lancet. Oncology 15(12), e538-e548. Available at:

https://doi.org/10.1016/S1470-2045(14)70442-5.

Rizzo, J.D., Brouwers, M., Hurley, P., Seidenfeld, J., Arcasoy, M.O., Spivak, J.L., Bennett, C.L., Bohlius, J., Evanchuk, D., Goode, M.J., Jakubowski, A.A., Regan, D.H., Somerfield, M.R., American Society of Clinical Oncology, \& American Society of Hematology, 2010. American Society of Clinical Oncology/American Society of Hematology clinical practice guideline update on the use of epoetin and darbepoetin in adult patients with cancer. Journal of clinical oncology: official journal of the American Society of Clinical Oncology 28(33), 4996-5010. Available at: https://doi.org/10.1200/JCO.2010.29.2201.

Tandon, N., Sidana, S., Rajkumar, S.V., Gertz, M.A., Buadi, F.K., Lacy, M.Q., Kapoor, P., Gonsalves, W.I., Dispenzieri, A., Kourelis, T.V., Warsame, R., Dingli, D., Fonder, A.L.,
Hayman, S.R., Hobbs, M.A., Hwa, Y.L., Kyle, R.A., Leung, N., Go, R.S., Lust, J.A., Russell, S.J., Kumar, S.K., 2019. Outcomes with early response to first-line treatment in patients with newly diagnosed multiple myeloma. Blood advances 3(5), 744-750. Available at: https://doi.org/10.1182/bloodadvances.2018022806.

van de Donk, N.W., Mutis, T., Poddighe, P.J., Lokhorst, H.M., Zweegman, S., 2016. Diagnosis, risk stratification and management of monoclonal gammopathy of undetermined significance and smoldering multiple myeloma. International journal of laboratory hematology 38(Suppl 1), 110-122. Available at: https://doi.org/10.1111/ijlh.12504.

van de Donk, N., Pawlyn, C., Yong, K.L., 2021. Multiple myeloma. Lancet (London, England) 397(10272), 410-427. Available at: https://doi.org/10.1016/S01406736(21)00135-5.

Vélez, R., Turesson, I., Landgren, O., Kristinsson, S.Y., Cuzick, J., 2016. Incidence of multiple myeloma in Great Britain, Sweden, and Malmö, Sweden: the impact of differences in case ascertainment on observed incidence trends. BMJ open 6(1), e009584. Available at: https://doi.org/10.1136/bmjopen-2015-009584.

\title{
Мултипен миелом: третман и вкупно преживување
}

\author{
Светлана Крстевска Балканов ${ }^{1}$, Сања Трајкова ${ }^{1}$, Соња Генадиева Ставриќ ${ }^{1}$, \\ Александра Пивкова Велјановска ${ }^{1}$, Марија Попова Лабачевска ${ }^{1}$, \\ Дејан Спасовски ${ }^{2}$, Ирена Рамбабова Бушлетиќ ${ }^{3}$, Гоце Калчев ${ }^{4}$, \\ Ирина Пановска Ставридис ${ }^{1}$
}

\author{
${ }^{I}$ Универзитетска клиника за хематологија, Медицински факултет, \\ Универзитет „Св. Кирил и Методиј“, Мајка Тереза 17, \\ 1000 Скопје, Република Северна Македонија \\ ${ }^{2}$ Универзитетска клиника за ревматологија, Медицински факултет, \\ Универзитет „Св. Кирил и Методиј“, Мајка Тереза 17, \\ 1000 Скопје, Република Северна Македонија \\ ${ }^{3}$ Универзитетска клиника за нефрологија, Медицински факултет, \\ Универзитет „Св. Кирил и Методиј“, Мајка Тереза 17, \\ 1000 Скопје, Република Северна Македонија \\ ${ }^{4}$ Универзитет Каљари, Италија
}

Клучни зборови: мултипен миелом, ММ, автологна трансплантација на матични клетки, талидомид

Мултипен миелом (МM) е плазма-клеточен малигнитет при што моноклоналните плазма клетки се размножуваат во коскената срцевина што резултира со зголемено количество на моноклонален парапротеин (М протеин), деструкција на коските и нарушување на останатите хематопоетски клеточни линии.

Прикажаната ретроспективно-проспективна студија беше спроведена на Универзитетската клиника за хематологија во Скопје, Северна Македонија, во периодот помеѓу јануари 2009 и декември 2019 година. Помладите пациенти над 65 години, без коморбидитети, погодни за автологна трансплантација на матични клетки од периферна крв (PBSCT), беа третирани со протокол Циклофосфамид-Талидомид-Дексаметазон (CyThalDex) поделен на две дневни дози кои се одржуваа до целосна ремисија. Постарите пациенти постари од 65 години, непогодни за поагресивни опции за третман како матични клетки од периферна крв (PBSCT) со коморбидитети и 
бубрежна инсуфициенција, беа третирани со протокол Мелфалан-Преднизон-Талидомид (МПТ). Третата група беше групата третирана без нови имуномодулатори како што е Талидомид; беше дадена терапија која се состоеше од хемотерапија и кортикостероиди.

Употребата на талидомид може да доведе до повеќе непосакувани ефекти како што се тромбоза на длабоките вени и бубрежна невропатија. Во согласност со резултатите од нашата студија, голем процент од овие ефекти не се регистрирани. Сепак, беше регистрирано подобро преживување со подолг период без прогресија на основната болест (ПФС) и воопшто постигнување поголем процент на целосна ремисија (ЦР) и многу добар делумен одговор (ВГПР).

Мултипниот миелом е сеуште неизлечива болест со модел на регресија и ремисија проследена со повеќекратни рецидиви што произлегуваат од резидуалните клетки на миеломот, при што во иднина се уште треба да се даде одговор на многу нерешени прашања.

Maced. pharm. bull., 67 (1) $79-90$ (2021) 